\title{
Analysis the Relationship Between the Distance of Groundwater Wells to the Septic Tank on Groundwater Quality
}

\author{
Anni Z. Putri ${ }^{1}$, Djoko M. Hartono ${ }^{2 *}$, and Sandyanto Adityosulindro ${ }^{3}$ \\ ${ }^{1,2,3}$ Civil and Environmental Engineering Department, Faculty of Engineering, Universitas Indonesia, \\ Depok, 16424, Indonesia
}

\begin{abstract}
.
Groundwater plays an important role in human life as it is often used in daily life and used as raw water for drinking water. This study aims to determine the quality of groundwater in several public facilities buildings at one of the campuses in Indonesia and to analyze the relationship between the distance of groundwater well to the septic tank to the parameters of groundwater quality. A total of 34 groundwater samples were collected from different bore wells and analysed for water quality parameters such as $\mathrm{pH}$, TDS, nitrate, manganese, and E. coli. $\mathrm{pH}$ and TDS was measured by $\mathrm{pH}$ meter and TDS meter; nitrate and manganese were determined using a spectrophotometer. The E. coli concentrations were determined by the Most Probable Number (MPN). The results of the analysis showed that the concentration range of TDS (11-194 mg/L), nitrate (0.35-12.45 mg/L), manganese (0.1-12.8 mg/L), E. coli (0-49 CFU/100ml), and $\mathrm{pH}$ value $(4.50-8.45)$. The results of the chi-square test showed that the distance between bore wells and septic tank did not have a significant relationship to the quality of groundwater with $\mathrm{pH}$, TDS, nitrate, and manganese parameters with Asymp. Sig. > 0.05. However, the distance between bore wells and septic tank has a significant relationship to the parameter E. coli with the Asymp. Sig. $0.035<0.05$.
\end{abstract}

Keywords: Groundwater quality, physicochemical biological parameters, chi-square analysis, and septic tank

\section{Introduction}

One of the sources of raw water that is often used to meet water needs is the use of ground water (Putri et al., 2013; Rezaei et al., 2019). Utilization of groundwater is considered practical and economical and its water quality is better than surface water (Hadian et al., 2015; Moyo, 2013; Putra \& Mairizki, 2020). Groundwater is seen as one of the potential sources of raw water in meeting its water needs. The main need for humans is clean water as it can be used as raw water for drinking water. 
The use of groundwater in Indonesia is still high, as seen by the large number of public facility buildings that use ground water because of its use as a replacement water reserve in case of problems in the distribution of clean water or clean water services and there are network leaks in pipes in the building area. However, the use of groundwater is not certain about its safety in terms of water quality. In its use, ground water must meet the quality of clean water to be safe for use. Good water quality must meet standards for physical, chemical and biological parameters. Pollution that enters groundwater can lead to poor groundwater quality (Nas \& Berktay, 2010; Saldanela et al., 2015). Groundwater quality is as important as groundwater quantity because of the suitability of water for various purposes (Nosrati \& Eeckhaut, 2012). Water quality is an important concern for humans because it is related to human welfare (Balakrishnan et al., 2011). Many factors can affect the quality of water resources both naturally, such as the influence of geological factors and rocks, and unnaturally such as the presence of domestic waste entering the ground or water bodies and the presence of septic tanks close to water sources (Cheong et al., 2012; Hadian et al., 2015; Rohmah et al., 2018; Venkatesan et al., 2020). The distance between the well and the septic tank $<10$ meters has a high correlation with pollution in groundwater (Dayanti et al., 2018). Groundwater quality needs to be monitored intensively to ensure that the groundwater used is proper and safe to use.

This research was conducted at one of the campuses in Indonesia to see the quality of bore wells water located in public facilities buildings. This location was chosen because based on a survey that has been conducted on these buildings, the use of nonpiped clean water sources originating from groundwater has long been applied. This is because the distribution of clean water from the Regional Drinking Water Company cannot meet the water needs of the building and the water discharge is too small. The use of groundwater for drinking water needs to meet the requirements of physical, chemical and biological parameters in accordance with the Ministry of Health Regulation Republic of Indonesia No. 32 of 2017. Therefore, this study aims to determine the quality of groundwater and to analyze the relationship between groundwater quality and the distance of groundwater wells to the septic tank pollutant sources. To see the relationship between variables, a statistical analysis will be carried out using the chi-square test. Chi-square test or often referred to as Pearson Chisquare aims to determine the relationship between the independent variable (distance of the well to the septic tank) and the dependent variable (groundwater quality parameters). Chi-square is a statistical study that is very useful in testing hypotheses with variables in the form of nominal data (Mchugh, 2013). Chi-square statistical analysis was performed with Statistical Package for the Social Sciences (SPSS) where if the value of Asymptotic Significance (Asymp. Sig.) < 0.05, there is a significant relationship between the independent and dependent variables (Tropea et al., 2021).

\section{Methods}

Groundwater samples were collected from bore wells located in public facility buildings at one of the campuses that have used ground water as clean water. A total of 34 groundwater samples that have been collected will be examined for analysis 
physico-chemical and microbiological. Groundwater sampling has been carried out in accordance with SNI 6989.59:2008 concerning Water and Wastewater - Section 58: Groundwater Sampling Procedures. Groundwater sampling was carried out through tap water at each sampling location by draining water from the valve for 1 to 2 minutes and then putting it into a container according to the criteria.

Testing of groundwater samples in this study included direct measurements in the field to examine $\mathrm{pH}$ and Total Dissolved Solids (TDS) using $\mathrm{pH}$ meter (SNI 066989.11:2004) and TDS meter (SNI 06-6989.1:2004). Meanwhile, for checking chemical properties; nitrate and manganese were determined using a spectrophotometer in accordance with APHA, then to examine the parameters of biological properties; Escherichia Coli (E. coli) was determined by the Most Probable Number (MPN) method in the laboratory. The results of the examination of pH, TDS, nitrate, manganese, and $E$. coli parameters will be compared with quality standards of the Ministry of Health Regulation Republic of Indonesia No. 32 of 2017. Statistical analysis Chi-square test was used to analyze the relationship between the distance of bore wells to the septic tank to the water quality parameters. All statistical analysis were performed using IBM SPSS version-21. The distance from the bore wells to the septic tank, he depth of the bore wells, and the age of the bore wells will be show in Table 1 . There are 36 sampling locations, but in this study the total sample collected was 34 groundwater samples. This happens because at point GG, groundwater samples from the three points are combined in one water reservoir.

Table 1: The distance from bore wells to septic tank at each location point

\begin{tabular}{|c|c|c|c|}
\hline Location Point & Distance $(\mathrm{m})$ & Depth $(\mathrm{m})$ & Age (year) \\
\hline AA1 & 14.3 & - & - \\
\hline AA2 & 13.5 & - & 3 \\
\hline BB1 & 35.2 & 75 & 30 \\
\hline CC1 & 33.8 & 50 & 30 \\
\hline CC2 & 30.6 & 50 & 31 \\
\hline DD & 42.8 & 25 & 31 \\
\hline EE & 3.9 & 25 & 2 \\
\hline FF & 10.1 & 25 & - \\
\hline GG & 13.6 & - & - \\
\hline GG & 14.0 & - & - \\
\hline GG & 12.3 & - & 20 \\
\hline HH1 & 23.3 & 50 & 13 \\
\hline HH2 & 13.1 & 50 & 13 \\
\hline II1 & 25.3 & 60 & 13 \\
\hline II2 & 21.4 & 60 & 13 \\
\hline II3 & 40.5 & 60 & - \\
\hline II4 & 43.1 & 60 & - \\
\hline JJ & 54.4 & & 20 \\
\hline
\end{tabular}




\begin{tabular}{|c|c|c|c|}
\hline Location Point & Distance $(\mathrm{m})$ & Depth $(\mathrm{m})$ & Age (year) \\
\hline KK1 & 26.2 & 50 & - \\
\hline KK2 & 22.8 & 150 & - \\
\hline KK3 & 28.6 & 50 & - \\
\hline KK4 & 21.5 & 50 & - \\
\hline KK5 & 36.9 & 50 & - \\
\hline KK6 & 18.1 & 50 & - \\
\hline KK7 & 26.2 & 50 & - \\
\hline KK8 & 10.7 & 50 & 10 \\
\hline LL & 49.6 & - & 10 \\
\hline MM1 & 26.6 & 25 & 10 \\
\hline MM2 & 30.7 & 25 & 10 \\
\hline MM3 & 8.2 & 25 & 10 \\
\hline MM4 & 22.5 & 25 & 10 \\
\hline MM5 & 20.6 & 25 & 10 \\
\hline MM6 & 21.5 & 25 & 2 \\
\hline NN & 50.5 & 30 & 2 \\
\hline OO1 & 120.2 & 45 & 45 \\
\hline OO2 & 147.1 & & - \\
\hline
\end{tabular}

(-): No information

\section{Results and Discussion}

\subsection{Power Hydrogen (pH)}

The $\mathrm{pH}$ value of the measured groundwater samples ranged from 4.50 to 8.45 with an average $\mathrm{pH}$ of 6.36 . A total of 18 samples of groundwater $(52.94 \%)$ showed acidic conditions and did not comply with the $\mathrm{pH}$ standard permitted by the Ministry of Health Regulation, namely 6.5-8.5 (Figure 1). Meanwhile, there were 16 samples of groundwater $(47.06 \%)$ whose groundwater conditions meet the standards for clean water needs. The results of statistical analysis using chi-square showed that the distance from the bore wells to the septic tank (Asymp. Sig. $0.932>0.05$ ) did not have a significant relationship with the $\mathrm{pH}$ parameter. The low $\mathrm{pH}$ value in groundwater is probably caused by waste from human activities and geological factors such as rocks which can affect groundwater conditions (Hadian et al., 2015). A pH level smaller than 4.8 and greater than 9.2 can be considered polluted, because water that is too alkaline or too acidic will kill aquatic plants and animals (Amri et al., 2018; Widiastuti et al., 2018). 


\section{$7^{\text {th }}$ International Conference On}

Modern Approaches in SCIENCE,

TECHNOLOGY \& ENGINEERING

18-20 June, 2021

Brussels, Belgium

Figure 1. pH value of groundwater

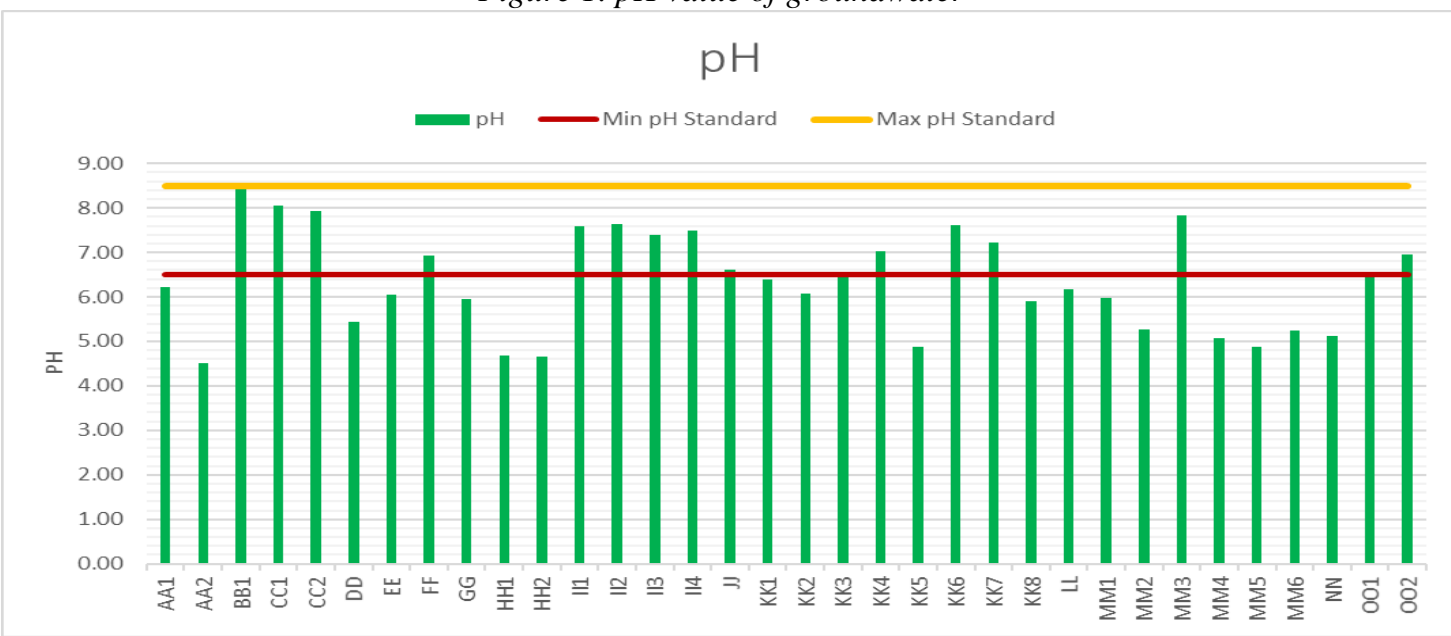

\subsection{Total Dissolved Solids (TDS)}

Total dissolved solids (TDS) is one of the main factors affecting water quality. In this study, TDS concentration in all groundwater samples $(n=34)$ (Figure 2) showing $100 \%$ results with good conditions for clean water needs and meet the quality standard requirements of the Ministry of Health Regulation, namely $1000 \mathrm{mg} / \mathrm{L}$. The average TDS concentration in groundwater was $91.86 \mathrm{mg} / \mathrm{L}$, which ranged from 11$194 \mathrm{mg} / \mathrm{L}$. Low TDS concentrations can be caused by natural filtration by rocks through groundwater (Hadian et al., 2015). Based on Currell et al., (2010), the low TDS concentration can be influenced by the condition of the age of the well and the source of groundwater originating from deep groundwater. WHO (2003) states that water with high TDS levels can lead to excessive scale on water pipes and household appliances. High concentrations of TDS can affect the clarity, hardness, taste, and color of groundwater (Arulnangai et al., 2020). The results of the chi-square test for the TDS parameter did not show the value of Asymp. Sig, this is influenced by the concentration of TDS in all groundwater samples which is constant and all samples meet regulatory standards.

Figure 2. Concentration of TDS in groundwater 


\section{$7^{\text {th }}$ International Conference On}

Modern Approaches in SCIENCE,

TECHNOLOGY \& ENGINEERING

18-20 June, 2021

Brussels, Belgium

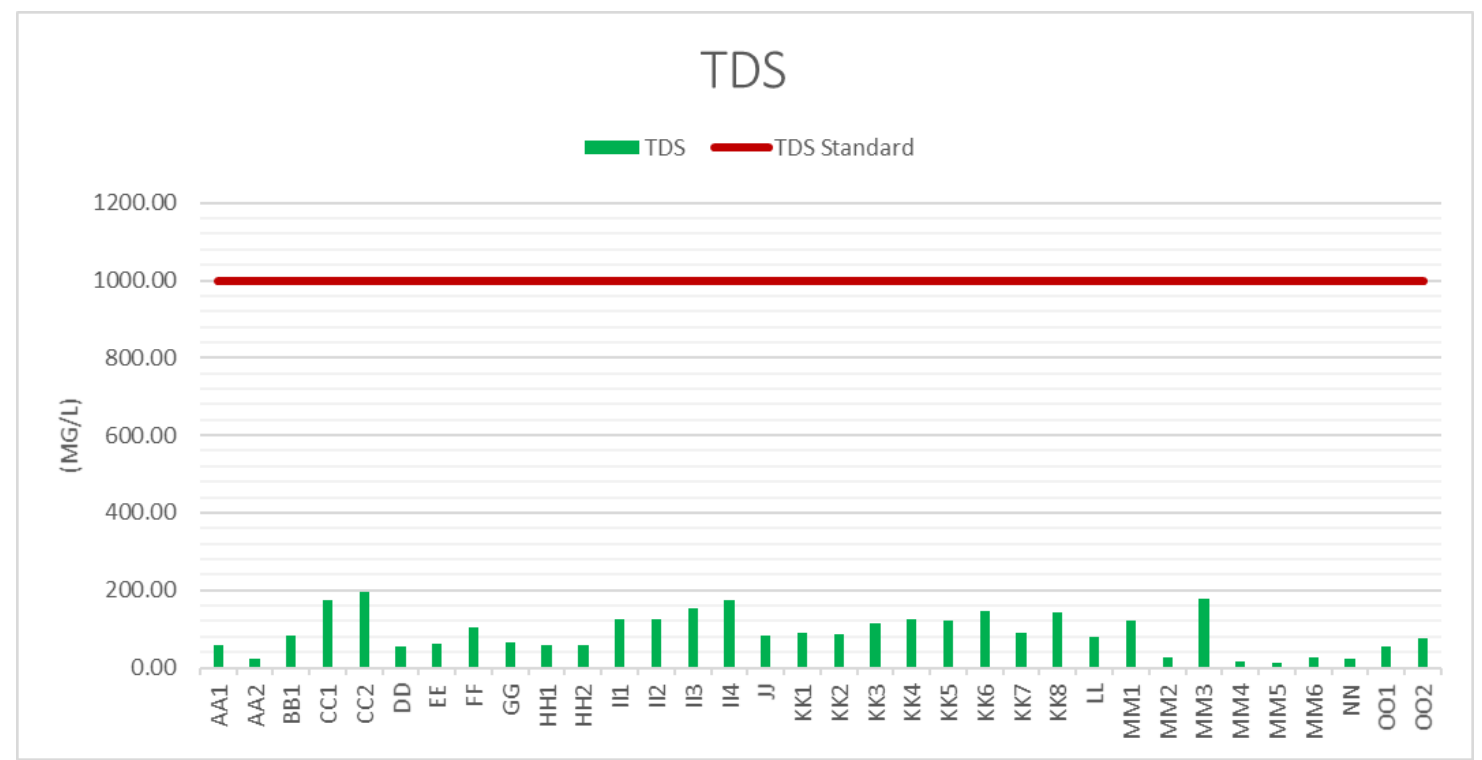

\subsection{Nitrate}

The concentration of nitrate in groundwater samples at the research location ranged from 0.35 to $12.45 \mathrm{mg} / \mathrm{L}$ with an average of $4.20 \mathrm{mg} / \mathrm{L}$. Most of the nitrate concentrations in the study location were 31 samples of groundwater $(91.18 \%)$, indicating that the groundwater conditions met the standards for clean water needs, except for three samples $(8.82 \%)$ with nitrate concentrations above the standard determined by the Ministry of Health Regulation is $10 \mathrm{mg} / \mathrm{L}$, namely for DD, HH2 and KK5 samples (Figure 3). Higher nitrate concentrations can damage human health such as methemoglobinemia, stomach cancer, goiter, birth defects and hypertension (Annapoorna \& Janardhana, 2015). The presence of nitrate in groundwater can come from anthropogenic, domestic waste, septic tank waste, organic nitrogen in the soil (Cheong et al., 2012). The analysis of chi-square showed that the distance between the bore wells and the septic tank did not have a significant relationship with nitrate parameters in groundwater (Asymp. Sig. $0.650>0.05$ ). The main source that can cause nitrate in groundwater is due to improper disposal of waste to the soil and water bodies (Venkatesan et al., 2020).

Figure 3. Concentration of Nitrate in groundwater 


\section{$7^{\text {th }}$ International Conference On}

Modern Approaches in SCIENCE,

TECHNOLOGY \& ENGINEERING

18-20 June, 2021

Brussels, Belgium

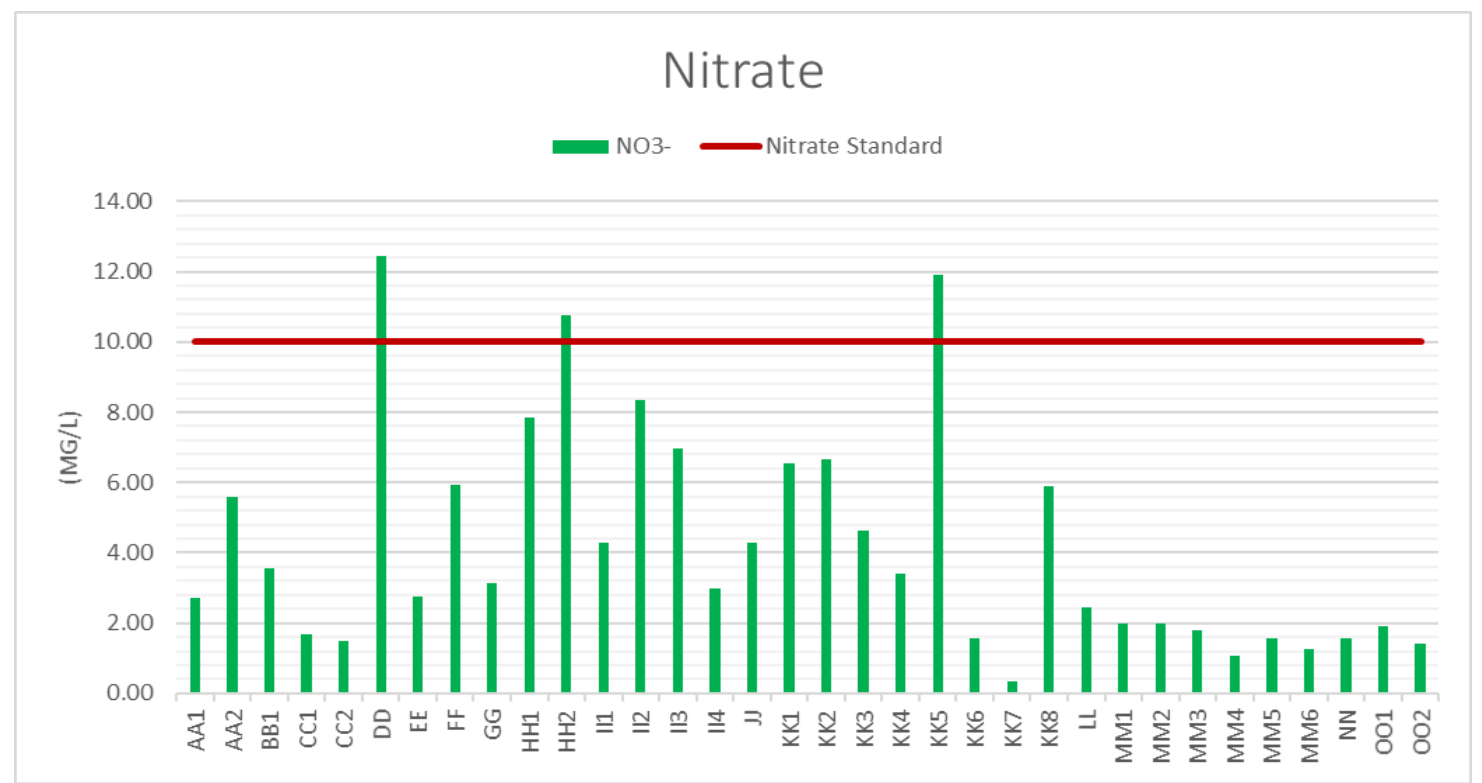

\subsection{Manganese}

The concentration of manganese in groundwater ranges from $0.1-12.8 \mathrm{mg} / \mathrm{L}$ with an average $0.82 \mathrm{mg} / \mathrm{L}$. Most of the manganese concentration showed good results to be used as clean water. A total of 24 groundwater $(70.59 \%)$ indicated that groundwater conditions were in accordance with the manganese standard permitted by the Ministry of Health Regulation, namely $0.5 \mathrm{mg} / \mathrm{L}$. However, there were 10 samples of groundwater $(29.41 \%)$ which showed manganese concentrations above the predetermined standard (Figure 4). The results of statistical analysis showed that the Asymp. Sig. $0.510>0.05$ indicates no significant relationship between the bore wells distance to the septic tank and the water quality parameter manganese. Higher manganese concentrations usually occur in old wells with deeper depths and the influence of rock lithology (Moyo, 2013; Putri et al., 2013). The low concentration of $\mathrm{pH}$ in water or groundwater that is too acidic will also easily cause high metal levels so that the water becomes colored, smells and tastes (Putra \& Mairizki, 2020). At the point MM1 the concentration of manganese reached $12.8 \mathrm{mg} / \mathrm{L}$. Beside be affected by the condition of the well is old, The presence of a lake with a distance more or less 47 meters from the well may affect the high concentration of manganese in groundwater at point MM1. As explained by Abadi et al., (2011) that runoff and seepage from surface water can increase the status of water to become highly polluted.

Figure 4. Concentration of Manganese in groundwater 


\section{$7^{\text {th }}$ International Conference On}

Modern Approaches in SCIENCE,

TECHNOLOGY \& ENGINEERING

18-20 June, 2021

Brussels, Belgium

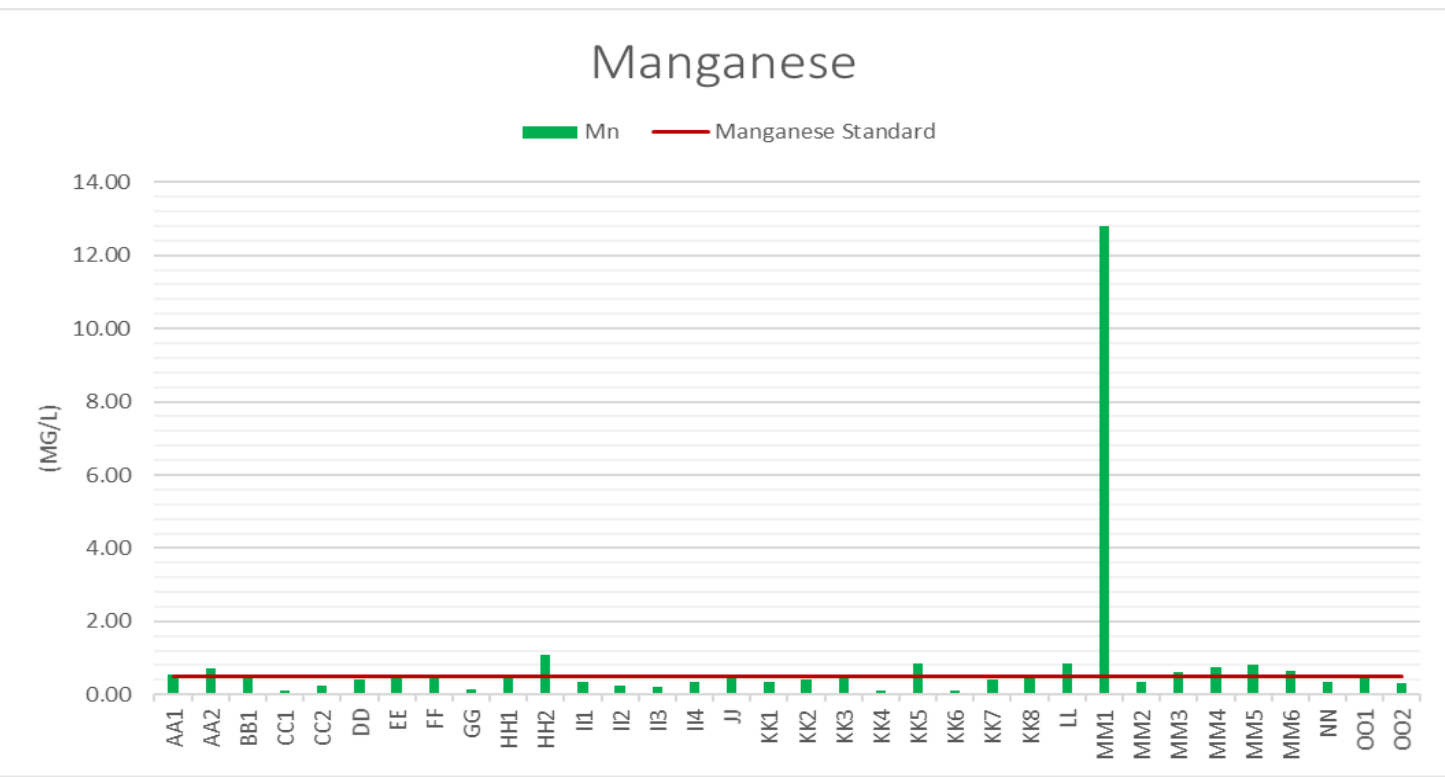

\subsection{Escherichia coli (E. coli)}

Escherichia Coli (E. coli) bacteria are pollutant indicator bacteria where water has been contaminated by human feces (Widiyanti, 2019). Based on the Regulation of the Minister of Health of the Republic of Indonesia No. 32 of 2017, the concentration of E. coli in groundwater must be $0 \mathrm{CFU} / 100 \mathrm{ml}$. Figure 5 shows that 11 samples of groundwater $(21.35 \%)$ were contaminated by E. coli and 23 samples of groundwater $(67.65 \%)$ indicated that the water quality had met the quality standards. E. coli concentrations in groundwater ranged from 0 to $49 \mathrm{CFU} / 100 \mathrm{ml}$ and averaged 5.01 CFU/100 ml. The high concentration of $E$. coli in groundwater can be influenced by the presence of wells with septic tanks that are too close together (Dey et al., 2017; Owamah et al., 2021; Rohmah et al., 2018) or not in accordance with regulatory standards as the minimum distance wells and septic tank is 10 meters (Badan Standardisasi Nasional Indonesia, 2017). In this study, the results of statistical analysis explain that the distance of the bore wells to the septic tank has a relationship with the emergence of E. coli in groundwater (Asymp. Sig. $0.035<0.05$ ).

Figure 5. Concentration of E. coli in groundwater 


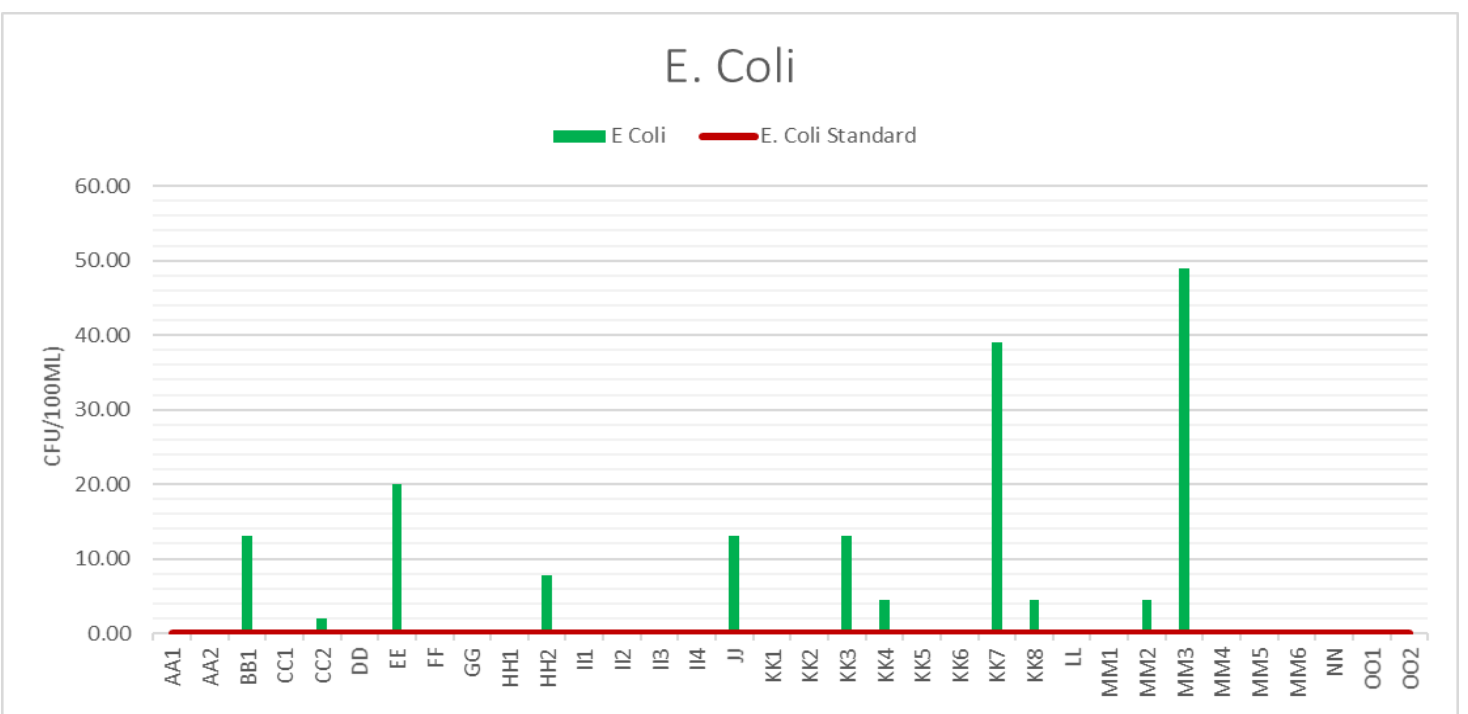

\section{Conclusion}

The results showed that $26.47 \%$ of the 34 samples studied had good quality groundwater to be used as clean water. The TDS and nitrate parameters with an average of $91.86 \mathrm{mg} / \mathrm{L}$ and $4.20 \mathrm{mg} / \mathrm{L}$ have met the standards for clean water needs which are in accordance with the regulation of the Ministry of Health Regulation Republic of Indonesia No. 32 of 2017. Whereas for $\mathrm{pH}$, manganese, and E. coli parameters with an average of $6.36 \mathrm{mg} / \mathrm{L} ; 0.82 \mathrm{mg} / \mathrm{L}$; and $5.01 \mathrm{CFU} / 100 \mathrm{ml}$ do not meet quality standards. In this case study, the chi-square test was used to analyze the relationship between the distance of bore wells to the septic tank on all water quality parameters. The results of statistical analysis showed that the variable distance between the bore wells and the septic tank had a significant relationship with the emergence of E. coli in groundwater (Asymp. Sig. $0.035<0.05)$. Meanwhile, there was no significant relationship (Asymp. Sig.. > 0.05) between the variable distance of the bore wells to the the septic tank with $\mathrm{pH}$, TDS, nitrate, and manganese parameters.

\section{Acknowledgment}

The authors would like to thank the Universitas Indonesia for supporting this research. We would also like to thank the Universitas Indonesia Environmental Health and Engineering Laboratory (TPLUI) for providing the facilities and resources to carry out this research.

\section{References}

Abadi, M. F., Mahendra, M. ., \& Suyasa, I. . B. (2011). Pemetaan Kualitas Air Tanah

Di Desa Dauh Puri Kaja Kota Denpasar. Ecotrophic: Journal of Environmental Science, 6(2), 77-80.

Amri, K., Muchlizar, M., \& Ma'mun, A. (2018). Variasi Bulanan Salinitas, Ph, Dan Oksigen Terlarut Di Perairan Estuari Bengkalis. Majalah Ilmiah Globe, 20(2), 57- 
66.

Annapoorna, H., \& Janardhana, M. R. (2015). Assessment of Groundwater Quality for Drinking Purpose in Rural Areas Surrounding a Defunct Copper Mine. Aquatic Procedia, 4(Icwrcoe), 685-692.

Arulnangai, R., Mohamed Sihabudeen, M., Vivekanand, P. A., \& Kamaraj, P. (2020). Influence of physico chemical parameters on potability of ground water in ariyalur area of Tamil Nadu, India. Materials Today: Proceedings, xxxx.

Badan Standardisasi Nasional Indonesia. (2017). Tata Cara Perencanaan Tangki Septik dengan Pengolahan Lanjutan (Sumur Resapan, Bidang Resapan, Up flow Filter, Kolam Sanita). In Jakarta. Jakarta.

Balakrishnan, P., Saleem, A., \& Mallikarjun, N. . (2011). Groundwater quality mapping using geographic information system (GIS): A case study of Gulbarga City, Karnataka, India. African Journal of Environmental Science and Technology, 5(12), 1069-1084.

Cheong, J. Y., Hamm, S. Y., Lee, J. H., Lee, K. S., \& Woo, N. C. (2012). Groundwater nitrate contamination and risk assessment in an agricultural area, South Korea. Environmental Earth Sciences, 66(4), 1127-1136.

Currell, M. J., Cartwright, I., Bradley, D. C., \& Han, D. (2010). Recharge history and controls on groundwater quality in the Yuncheng Basin, north China. Journal of Hydrology, 385(1-4), 216-229.

Dayanti, M. P., Fachrul, M. F., \& Wijayanti, A. (2018). Escherichia coli as bioindicator of the groundwater quality in Palmerah District, West Jakarta, Indonesia. IOP Conference Series: Earth and Environmental Science, 106(1).

Dey, N. C., Parvez, M., Dey, D., Saha, R., Ghose, L., Barua, M. K., Islam, A., \& Chowdhury, M. R. (2017). Microbial contamination of drinking water from risky tubewells situated in different hydrological regions of Bangladesh. International Journal of Hygiene and Environmental Health, 220(3), 621-636.

Hadian, M. S. D., Azy, F. N., Krismadiyanti, I., Arfani, D. L., Sofyan, E. T., \& Prayogi, T. E. (2015). Groundwater Quality Assessment for Suitable Drinking and Agricultural Irrigation Using Physico-Chemical Water Analysis in the RancaekekJatinangor District, West Java, Indonesia. International Conference on Environmental Science and Technology, 84, 56-62.

Mchugh, M. L. (2013). The Chi-square test of independence Lessons in biostatistics. Biochemia Medica, 23(2), 143-149.

Moyo, N. A. G. (2013). An analysis of the chemical and microbiological quality of ground water from boreholes and shallow wells in Zimbabwe. Physics and Chemistry of the Earth, 66, 27-32.

Nas, B., \& Berktay, A. (2010). Groundwater Quality Mapping in Urban Groundwater Using GIS. Environmental Monitoring and Assessment, 160(1-4), 215-227. 
Nosrati, K., \& Eeckhaut, M. Van Den. (2012). Assessment of groundwater quality using multivariate statistical techniques in Hashtgerd Plain, Iran. Environmental Earth Sciences, 65(1), 331-344.

Owamah, H. I., Alfa, M. I., Oyebisi, S. O., Emenike, P. C., Otuaro, E. A., Gopikumar, S., \& Kumar, S. S. (2021). Groundwater quality monitoring of a popular Niger Delta university town in Nigeria. Groundwater for Sustainable Development, 12(August 2020), 100503.

Putra, A. Y., \& Mairizki, F. (2020). Groundwater Quality Assessment for Drinking Purpose Based on Physicochemical Analysis in Teluk Nilap Area, Rokan Hilir, Riau, Indonesia. Journal of Geoscience, Engineering, Environment, and Technology, 5(3), 170-174.

Putri, L. S. E., Kustanti, N., \& Yunita, E. (2013). Effect of Land Use on Ground Water Quality (A Case Study from Ciracas Sub District, East Jakarta, Indonesia). International Journal of Bioscience, Biochemistry and Bioinformatics, 3(1), 33-36.

Rezaei, A., Hassani, H., Hassani, S., Jabbari, N., Fard Mousavi, S. B., \& Rezaei, S. (2019). Evaluation of groundwater quality and heavy metal pollution indices in Bazman basin, southeastern Iran. Groundwater for Sustainable Development, 9(May), 100245.

Rohmah, Y., Rinanti, A., \& Hendrawan, D. I. (2018). The determination of ground water quality based on the presence of Escherichia coli on populated area (a case study: Pasar Minggu, South Jakarta). IOP Conference Series: Earth and Environmental Science, 106(1).

Saldanela, Sutikno, S., \& Hendry, A. (2015). Pemetaan Pola Aliran Air Tanah Berbasis Sistem Informasi Geografis (SIG) Di Kawasan Kecamatan Tampan Kota Pekanbaru. Jom FTEKNIK, 2(1), 1-8.

Tropea, E., Hynds, P., McDermott, K., Brown, R. S., \& Majury, A. (2021). Environmental adaptation of E. coli within private groundwater sources in southeastern Ontario: Implications for groundwater quality monitoring and human health. Environmental Pollution, 285(December 2020), 117263.

Venkatesan, G., Subramani, T., Sathya, U., \& Roy, P. D. (2020). Seasonal changes in groundwater composition in an industrial center of south India and quality evaluation for consumption and health risk using geospatial methods. Chemie Der Erde, 80(4), 125651.

WHO. (2003). Total dissolved solids in Drinking-water Background document for development of WHO Guidelines for Drinking-water Quality. In World Health Organization (2nd ed., Vol. 2). Geneva, Switzerland: World Health Organization.

Widiastuti, A., Hartono, D. M., \& Moersidik, Setyo S., \& Gusniani, I. (2018). Characteristics of Leachate and Their Effect on Shallow Groundwater Quality (Case Study: TPA Cipayung, Depok). IOP Conference Series: Earth and Environmental Science, 120(1). 


\section{$7^{\text {th }}$ International Conference On}

Modern Approaches in SCIENCE, TECHNOLOGY \& ENGINEERING

18-20 June, 2021

Brussels, Belgium

Widiyanti, B. L. (2019). Studi Kandungan Bakteri E.Coli pada Airtanah (Confined Aquifer) di Permukiman Padat Penduduk Desa Dasan Lekong, Kecamatan Sukamulia. Geodika: Jurnal Kajian Ilmu Dan Pendidikan Geografi, 3(1), 1-12. 